\title{
Vivaldi 1991 - A study of the formation, circulation and ventilation of Eastern North Atlantic Central Water
}

\author{
R. T. POLLARD, ${ }^{*}$ M. J. GRIFFITHS, ${ }^{*}$ S. A. CUNNINGHAM, ${ }^{*}$ J. F. READ, ${ }^{*}$ F. F. PEREZ** \\ and A. F. RIOS** \\ *Southampton Oceanography Centre, Empress Dock, Southampton S014 3ZH, UK \\ **Instituto de lnvestigacions Mariñas, Eduardo Cabello 6, 36208 Vigo, Spain
}

Abstract - A synoptic, hydrographic data set comprising 32 full depth CTD casts and $2500 \mathrm{CTD} / \mathrm{SeaSoar}$ profiles to $500 \mathrm{~m}$ is used to describe the $\theta / \mathrm{S}$ properties and circulation of Central Water east of the mid-Atlantic Ridge and between $39^{\circ} \mathrm{N}$ and $54^{\circ} \mathrm{N}$. Eastward transport of $20 \times 10^{6} \mathrm{~m}^{3} \mathrm{~s}^{-1}$ in the North Atlantic Current turns entirely northwards to the west of $54^{\circ} \mathrm{N}, 20^{\circ} \mathrm{W}$. This transport consists in the upper layers of Western North Atlantic Water freshened at temperatures below $10^{\circ} \mathrm{C}$ by mixing with SubArctic Intermediate Water. Northern and Southern branches of the North Atlantic Current are well defined and both turn northwards west of $20^{\circ} \mathrm{W}$. A further $10 \times 10^{6} \mathrm{~m}^{3}$ $\mathrm{s}^{-1}$ of Eastern North Atlantic Water forms and recirculates anticyclonicaily to the west of Spain south of the North Atlantic Current and north of $40^{\circ} \mathrm{N}$. Eastern North Atlantic Water is most weakly stratified east of $20^{\circ} \mathrm{W}$ and there is clear correlation between weakly stratified pycnostads and positive salinity anomalies relative to Western North Atlantic Water. Thus Eastern North Atlantic Water is a winter Mode Water in which strong winter cooling has increased the density and hence also the salinity anomaly at a given temperature. Near the southern entrance to the Rockall Trough there is evidence that salinities are also increased by Mediterranean Water influence. Circulation south of the North Atlantic Current is complex. There is no evidence for direct ventilation southwards across $40^{\circ} \mathrm{N}$ where water properties $(\theta / \mathrm{S}$, potential vorticity and CFC-113) and historical data all indicate westward ventilation east of $24^{\circ} \mathrm{W}$, with weak southward ventilation occurring further west, in the vicinity of the Azores. The circulation pattern suggested is remarkably similar to that proposed by Helland-Hansen and Nansen in 1926 (The eastern North Atlantic, Geophysiske Publicajoner, 4, 1-76), with anticyclonic circulation of colder Eastern North Atlantic Water north of $40^{\circ} \mathrm{N}$ meeting warmer water from south of $40^{\circ} \mathrm{N}$ circulating cyclonically north of the Azores Current. The distribution of pycnostads and $\theta / \mathrm{S}$ properties between $20^{\circ} \mathrm{W}$ and $35^{\circ} \mathrm{W}$ north of the Azores indicates alternate bands of Western and Eastern North Atlantic Water 
moving eastward and westward respectively, including evidence for westward motion immediately south of the Southern branch of the North Atlantic Current, possibly by westward propagation of anticyclonic eddies containing deep pycnostads.

\section{INTRODUCTION}

Northeast of the Azores there is a region of weak circulation, bounded to the north and south by the North Atlantic Current (NAC) and the Azores Current respectively, and to the east and west by Europe and the mid-Atlantic Ridge. If we take the subpolar gyre to be bounded to the south by the NAC, and the subtropical gyre to be bounded to the north by the Azores Current, then the weak circulation region is an intergyre zone. However, POLLARD and $\mathrm{Pu}(1985)$ reviewed the circulation of this region and concluded that the saline upper layer, shallowing to the north, was the northern outcrop of the anticyclonic, subtropical gyre, with weak eastward to southeastward circulation in much of the region. This paper re-examines the circulation using a new, synoptic (collected over six weeks) data set and reaches rather different conclusions.

The upper $500 \mathrm{~m}$ of the intergyre zone is entirely occupied by North Atlantic Central Water (NACW). Central Water is the body of water in the upper 500-1000 m of the ocean whose well-defined T/S characteristics have been formed primarily by air-sea interaction across a wide band of latitudes (ISELIN, 1939). It has long been recognised (HARVEY, 1982; ISELIN, 1936; RIOS, PEREZ and FRAGA, 1992) that Central Waters in the eastern North Atlantic are more saline, usually by less than 0.1 (in salinity at a constant temperature) than those in the western North Atlantic, giving rise to the terms Western North Atlantic Water (WNAW) to describe Central Water with the characteristics found in the Sargasso Sea, and first described by ISELIN (1936), and Eastern North Atlantic Water (ENAW) for the more saline variety (HARVEY, 1982). HARVEY (1982) and others ascribed the higher salinity of ENAW to the influence of Mediterranean Water (MW). POLLARD and PU (1985) showed that air-sea interaction, in particular winter mixing, was a more likely cause, at least for densities $\sigma_{\theta}$ less than $27.3 \mathrm{~kg} \mathrm{~m}^{-3}$. ARHAN (1990) later invoked downward pumping of salt from NACW to the fresher SubArctic Intermediate Water (SAIW) beneath the NAC as another mechanism to account for the higher salinities of ENAW. Our data set, after averaging, consists of over $2500 \mathrm{CTD}$ profiles at $4 \mathrm{~km}$ intervals. With such high spatial resolution, 
and salinities calibrated to an absolute accuracy better than 0.01 , we are able to map the subtle differences between WNAW and ENAW, infer their circulation northeast of the Azores, and examine how ENAW gains its higher salinity.

POLLARD and $\mathrm{Pu}$ (1985) found that the $\theta / \mathrm{S}$ characteristics of the upper layers of the intergyre zone had changed from the late 1950 s to the late 1970 s, freshening by over 0.1 north of $40^{\circ} \mathrm{N}$ and between Europe and $30^{\circ} \mathrm{W}$. They concluded that air-sea interaction was the most likely cause of the freshening, but DICKSON, MEINCKE, MALMBERG and LEE (1988) found that much of the subpolar gyre had freshened in sequence, primarily by advection starting with the East Greenland Current. These hypotheses will be re-examined, and it will be found that, while advection acts to freshen ENAW, airsea interaction in cold winters plays a major role in increasing the salinity anomaly of ENAW on isopycnals.

The hydrographic data from CTD and SeaSoar will be introduced in section 2, and a gross view of the circulation derived. Although Acoustic Doppler Current Profiler data were also obtained, we have chosen not to present them in this paper. The reason is that, although ADCP data support our detailed conclusions on the circulation patterns, they provide only an instantaneous picture of the velocity field, in which mesoscale eddies dominate. Hydrographic data on the other hand, particularly water mass properties, provide a time integrated view, which is more helpful in a region in which mean circulation speeds are small. This paper is consequently strong on deriving patterns of circulation, but weak in determining circulation rates. $\theta / \mathrm{S}$ relationships are examined in detail in section 3, and the circulation in six separate density ranges is discussed in section 4. Finally, our findings are synthesised in the discussion in section 5.

\section{VIVALDI DATA}

\subsection{CTD casts}

During the six week period from 27 April to 8 June 1991, a survey of the northeast North Atlantic was carried out on RRS Charles Darwin (POLLARD, LEACH and GRIFFITHS, 1991) with CTD (GRIFFITHS, CUNNINGHAM, GRIFFITHS, POLLARD, LEACH, HOLLEY, PAYLOR, HAINE, RIOS, ALDERSON, LOWRY, 
SMITH, PRESTON, GWILLIAM, SMITHERS, KEENE, HEMMINGS and ANDERSON, 1992) and SeaSoar (CUNNINGHAM, GRIFFITHS, HEMMINGS, ALDERSON, GRIFFITHS, POLLARD, DONLAN, LANCASTER, LEACH, LOWRY, STIRLING, SMITH, GWILLIAM, SMITHER, KEENE, PEARCE, ANDERSON, BOWERMAN and GROHMANN, 1992) between $39^{\circ} \mathrm{N}$ and $54^{\circ} \mathrm{N}$ and between $12^{\circ} \mathrm{W}$ and $34^{\circ} \mathrm{W}$ (Fig. 1). Full depth CTD casts were made with a Neil Brown Mark 3 CTD at 32 positions sparsely spaced on a $3^{\circ}$ (latitude) by $300 \mathrm{~km}$ (longitude) grid (CUNNINGHAM and HAINE, 1995a, 1995b). These will be referred to by their latitude and line letter (e.g. W54 is $54^{\circ} \mathrm{N}$ on Line $\mathrm{W}, 34^{\circ} \mathrm{W}$ ), because the longitudes of each line vary. Note that the western boundary of the Vivaldi survey area, line W, is close to section F in MCCARTNEY and TALLEY (1982) and the western TOPOGULF line (e.g., ARHAN, 1990) (see Fig. 1).

To provide an overview of the upper ocean circulation, the volume transport of the upper $2000 \mathrm{~m}$ referenced to $2000 \mathrm{~m}$ is contoured in Fig. 2 from the CTD cast data. While the $300 \mathrm{~km}$ separation of CTD casts does not resolve mesoscale eddies nor conform to the WOCE standard (50 km or less), it was logistically necessary in order to swop between CTD station work and towed SeaSoar only about once per day. Nevertheless, Fig. 2 provides a guide to the mean circulation within which to interpret the more detailed SeaSoar data which will later confirm and extend the following description.

The NAC enters the survey area across line W north of $48^{\circ} \mathrm{N}$ carrying over $20 \mathrm{~Sv}$ (1 Sverdrup $\left.=10^{6} \mathrm{~m}^{3} \mathrm{~s}^{-1}\right)$, although the CTD casts do not resolve the northern and southern branches (HARVEY and ARHAN, 1988). The NAC appears to recirculate entirely to the north, and over $30 \mathrm{~Sv}$ cross $54^{\circ} \mathrm{N}$. No more than $25 \mathrm{~Sv}$ of this northward transport can be attributed to the NAC (SY, SCHAUER and MEINCKE, 1992), and Fig. 2 indicates that the NAC turns north primarily between $20-25^{\circ} \mathrm{W}$, with the remaining $5-10$ Sv entering the Rockall Trough east of $20^{\circ} \mathrm{W}$. Southeast of the NAC, several station pairs (A48-B48, A45-B45, Z45-A45) east of $20^{\circ} \mathrm{W}$ show southward transport of up to $12 \mathrm{~Sv}$, but across $42^{\circ} \mathrm{N}$ the transport is weakly northwards between Y42 and B42 (8 Sv). Thus the southward flow recirculates anticyclonically around $45^{\circ} \mathrm{N}, 15-20^{\circ} \mathrm{W}$. In the southwest comer of the survey area, the circulation is poorly resolved by the widely 
separated CTD casts, but there appears to be further anticyclonic circulation around X42 and southeastward flow past W39, the southwestern corner of the survey area.

Despite its coarseness, this description is consistent with recent papers that describe the upper ocean circulation northeast of the Azores. SY (1988) found that the NAC system changed its general direction towards the north after crossing the Mid-Atlantic Ridge, and that there was no significant southward turning of the flow (DIETRICH, KALLE, KRAUSS and SIEDLER, 1975, their Fig. 10.50, p 520) which could be interpreted as being part of the Gulf Stream recirculation. SCHMITZ and MCCARTNEY (1993), from the very small transports to the south across the line from the Azores to Portugal (STRAMMA, 1984; SY, 1988), postulated that Sub-Polar Mode Water recirculates in an anticyclonic gyre with an extended longitudinal scale, their Fig. 9d suggesting more or less westward flow east of the Azores. ONKEN (1993) discusses evidence for westward flow between $36^{\circ} \mathrm{N}$ and $40^{\circ} \mathrm{N}$ and concludes that there is a zonally elongated anticyclonic gyre between $36^{\circ} \mathrm{N}$ and the NAC. BOWERMAN and LEACH (1996), averaging several occupations of a section running northwest from the Azores (including VIVALDI, 1991), find westward flow of perhaps $0.04 \mathrm{~m} \mathrm{~s}^{-1}$ between the Azores and $44^{\circ} \mathrm{N}$.

While little attention has been drawn to it, there is substantial evidence from several data sets that there is westward flow across $20^{\circ} \mathrm{W}$ between $40^{\circ} \mathrm{N}$ and $45^{\circ} \mathrm{N}$. POLLARD and PU (1985), describing IGY data, noted the weakness of eastward flow between about $40^{\circ} \mathrm{N}$ and $46^{\circ} \mathrm{N}$. In fact, their Fig. 3 shows isopycnals sloping downwards to the north at longitudes from $10^{\circ} \mathrm{W}$ to $30^{\circ} \mathrm{W}$, indicating westward baroclinic transport (and SY (1988) concluded that the barotropic component in the region was negligible). Recent hydrographic sections along $20^{\circ} \mathrm{W}$ in 1988 (TSUCHIYA, TALLEY and MCCARTNEY, 1992), 1989 and 1990 (KING, ALDERSON, BACON, GWILLIAM, HIRST, PAYLOR, READ and SWALLOW, 1991; READ, POLLARD and HIRST, 1991; READ, POLLARD and KING, personal communication) and 1991 (this paper) all show westward baroclinic flow (relative to deep levels of no motion) between about $40^{\circ} \mathrm{N}$ and $45^{\circ} \mathrm{N}$ (also remarked on by PAILLET and ARHAN (1996). SeaSoar data will confirm this conclusion in Section 4.1.

\subsection{SeaSoar data}


The SeaSoar, containing a Neil Brown Mark 3 CTD, was towed along $10000 \mathrm{~km}$ of track between the CTD stations (Fig. 1), profiling from the surface to a depth of $500 \mathrm{~m}$ and back every $2.5 \mathrm{~km}$. The SeaSoar was basically as described by POLLARD (1986), but provided with a new winch with $800 \mathrm{~m}$ of faired cable to allow profiling significantly deeper than the $350 \mathrm{~m}-400 \mathrm{~m}$ previously possible. Salinities were carefully calibrated by comparison with CTD casts and underway surface salinities (CUNNINGHAM, GRIFFITHS, HEMMINGS, ALDERSON, GRIFFITHS, POLLARD, DONLAN, LANCASTER, LEACH, LOWRY, STIRLING, SMITH, GWILLIAM, SMITHERS, KEENE, PEARCE, ANDERSON, BOWERMAN and GROHMANN, 1992) to achieve an absolute calibration better than 0.01 throughout, and better than 0.005 for $97 \%$ of the data. The SeaSoar data were then reduced by averaging onto a $4 \mathrm{~km}$ (horizontal) by $8 \mathrm{~m}$ (vertical) grid, resulting in over $2500 \mathrm{CTD}$ profiles to $500 \mathrm{~m}$ at $4 \mathrm{~km}$ intervals. The majority of the SeaSoar tracks were nearmeridional, running along the six tracks $\mathrm{W}$ through $\mathrm{B}$ (Fig. 1) with Line $\mathrm{Z}$ exactly north-south along $20^{\circ} \mathrm{W}$.

Sections of potential temperature $(\theta)$, salinity $(\mathrm{S})$ and density $\left(\sigma_{0}\right)$ are shown in Fig. 3 for all six meridional lines $\mathrm{W}$ through $\mathrm{B}$. These plots show the structure of the top 500 $\mathrm{m}$ in unprecedented detail. Note first that there are plenty of features which can be traced zonally from one line to the next, such as the thermostad of $12.0^{\circ} \mathrm{C}-12.5^{\circ} \mathrm{C}$ water on lines $\mathrm{Y}$ (about $\left.24^{\circ} \mathrm{W}\right)$ and $\mathrm{Z}\left(20^{\circ} \mathrm{W}\right)$ between $41^{\circ} \mathrm{N}$ and $47^{\circ} \mathrm{N}$. Thus, although the 300 $\mathrm{km}$ separation of the lines does not allow mesoscale activity to be zonally traced, the evolution of the large-scale structure from west to east can be followed, though not always easily.

Note too the temporal development of the seasonal thermocline, which masks the Mode Water structure in the top $50-100 \mathrm{~m}$. The portions of the lines south of $48^{\circ} \mathrm{N}$ were occupied from east to west (Fig. 1) from 27 April (B48) to 15 May (X39), prior to a mid-cruise break in the Azores. Line $\mathrm{W}$ and the portions of the lines north of $48^{\circ} \mathrm{N}$ were occupied from west to east from 19 May (W39) to 8 June (A54). Thus the time gap between occupations of the southern and northern halves of each line is greatest for line A, where it is over a month (3 May to 5 June). The discontinuity in the seasonal thermocline at $48^{\circ} \mathrm{N}$ on line $\mathrm{A}$ is clearly apparent in temperature and density (but not in 
salinity, as the seasonal effect is primarily heating). Beneath the seasonal layer, in the depth range $50-500 \mathrm{~m}$, the only line which shows a significant discontinuity at $48^{\circ} \mathrm{N}$ is line A. The northward deepening of the $11^{\circ} \mathrm{C}$ and $11.5^{\circ} \mathrm{C}$ isotherms at that latitude is an artifact. On the first leg, these isotherms rose rapidly to the north at $47.8^{\circ} \mathrm{N}$, on the second leg they rose at $48.8^{\circ} \mathrm{N}$.

HARVEY and ARHAN (1988), using data from the French-German TOPOGULF programme in 1983 and 1984, identified northern and southern branches of the NAC. They defined the southern branch as the northern limit of "pure" NACW and the northern branch as the southern limit of outcropping SAIW. SY (1988) referred to the northern branch as the permanent subpolar front, topographically fixed to the Charlie Gibbs Fracture Zone $\left(52.5^{\circ} \mathrm{N}, 32^{\circ} \mathrm{W}\right)$, and noted that there are one or more transient southern branches. The western TOPOGULF line lay close to Vivaldi line W (Fig. 1), and ARHAN (1990), mapping the temperature at $300 \mathrm{~m}$, found a temperature change from $5^{\circ} \mathrm{C}$ to $7^{\circ} \mathrm{C}$ at the northern front at $51.5^{\circ} \mathrm{N}, 34^{\circ} \mathrm{W}$, and from $8^{\circ} \mathrm{C}$ to $12^{\circ} \mathrm{C}$ at the southern front or fronts around $47-48^{\circ} \mathrm{N}, 30^{\circ} \mathrm{W}$. Looking now at line W (Fig. 3a), it is clear that the northern branch of the NAC crosses $\mathrm{W}$ at $50.8^{\circ} \mathrm{N}, 33^{\circ} \mathrm{W}$ (somewhat south of the Gibbs Fracture Zone), where the temperature at $300 \mathrm{~m}$ changes from $5.5^{\circ} \mathrm{C}$ to $9^{\circ} \mathrm{C}$ in about $30 \mathrm{~km}$, and a clear, single, southern branch crosses $\mathrm{W}$ at $48.5^{\circ} \mathrm{N}, 32^{\circ} \mathrm{W}$, where the $300 \mathrm{~m}$ temperature changes from $9.5^{\circ} \mathrm{C}$ to $12^{\circ} \mathrm{C}$ also in $30 \mathrm{~km}$. These fronts are marked $\mathrm{N}$ and $\mathrm{S}$ on Fig. 3c and we shall sometimes refer to them as Front $\mathrm{N}$ and Front S. Similar temperature changes are apparent on line $X$ at $51.7^{\circ} \mathrm{N}$ and $49.8^{\circ} \mathrm{N}$, and on line $\mathrm{Y}$ at $50.9^{\circ} \mathrm{N}$ and $49.6^{\circ} \mathrm{N}$. Marked salinity changes are associated with all these fronts (Fig. 3b) which we may contour with some confidence from line $\mathrm{W}\left(33^{\circ} \mathrm{W}\right)$ to line $\mathrm{Y}\left(25^{\circ} \mathrm{W}\right)$, as shown on Fig. 2.

Between lines $\mathrm{Y}$ and $\mathrm{Z}\left(20^{\circ} \mathrm{W}\right)$ the NAC turns northwards (Fig. 2) and continuity of the fronts from $\mathrm{Y}$ to $\mathrm{Z}$ is less obvious. At a depth of $300 \mathrm{~m}$ along $20^{\circ} \mathrm{W}$, there are sudden temperature changes from $8^{\circ} \mathrm{C}$ to $9.5^{\circ} \mathrm{C}$ at $52.6^{\circ} \mathrm{N}$ and from $9.5^{\circ} \mathrm{C}$ to $11^{\circ} \mathrm{C}$ at $50^{\circ} \mathrm{N}$, but the slopes of isopyncals at those latitudes (Fig. 3c) are much reduced, so eastward transport is weaker. We defer detailed discussion of how the NAC turns until the $\theta / \mathrm{S}$ relations and anomalies from them have been derived in the next section. 
The two fronts so far introduced are not the only ones apparent in Fig. 3. For example, on line $\mathrm{Y}$ a third temperature front (Front 3) can be seen at $46.9^{\circ} \mathrm{N}$ where the $300 \mathrm{~m}$ temperature changes from $11^{\circ} \mathrm{C}$ to $12^{\circ} \mathrm{C}$. This has a clear counterpart to the east at $47.5^{\circ} \mathrm{N}$ on line $\mathrm{Z}$, but is less obvious to the west, though a weaker feature is seen on line $\mathrm{X}$ around $45.5^{\circ} \mathrm{N}$ which could be connected to features on line $\mathrm{W}$ at either $44^{\circ} \mathrm{N}$ or $47^{\circ} \mathrm{N}$. Again, detailed discussion must await examination of water mass anomalies. However, Front 3 is the northern boundary on lines $\mathrm{Y}$ and $\mathrm{Z}$ of the $12^{\circ} \mathrm{C}-12.5^{\circ} \mathrm{C}$ thermostad mentioned earlier in this section, and we conclude our introduction to the SeaSoar data by noting the variety of stads and their properties.

To allow examination of the pycnostads, isopycnals in Fig. 3c have been shown at even intervals of $0.05 \mathrm{~kg} \mathrm{~m}^{-3}$ everywhere. Pycnostads are apparent on all the survey lines at some locations by sudden meridional increases in the separation of isopycnals, or increasing thickness. Expanded scale plots of the associated thermostads at several locations are shown in Fig. 4 with contours at $0.2^{\circ} \mathrm{C}$ intervals. Some of these stads lie just beneath the seasonal thermocline, so could be caused by local winter mixing (e.g. $12.8-13.2^{\circ} \mathrm{C}$ on line $\mathrm{W}, 45^{\circ} \mathrm{N}-45.7^{\circ} \mathrm{N}$ ). Others are sufficiently subsurface (e.g. 12.8$13.2^{\circ} \mathrm{C}$, line $\mathrm{W}, 46.1^{\circ} \mathrm{N}-46.5^{\circ} \mathrm{N}$ ) that they must have subducted following their creation by winter mixing, the only way in which such thick (100 m or more), weakly stratified layers could have been created. One of the dominant stads, $12.0-12.4^{\circ} \mathrm{C}$ in Fig. 4 or $12.0-12.5^{\circ} \mathrm{C}$ in Fig. 3a, is clearly created by winter mixing on line B, and subducted to the south (lines $\mathrm{Z}$ and $\mathrm{Y}$ ) and west (line $\mathrm{X}, 40.5^{\circ} \mathrm{N}-42^{\circ} \mathrm{N}$ ). We shall examine several stads in detail later.

In overview, the stratification of the upper $500 \mathrm{~m}$ (excluding the seasonal stratification of the top $100 \mathrm{~m}$ ) decreases markedly from west to east. On line $\mathrm{W}$, the density increase from $100 \mathrm{~m}$ to $500 \mathrm{~m}$ is typically $0.3 \mathrm{~kg} \mathrm{~m}^{-3}$, whereas on lines A and B it is $0.1 \mathrm{~kg} \mathrm{~m}^{-3}$ or less. We shall show that the deepest winter mixing takes place east of $20^{\circ} \mathrm{W}$, and use the properties of the pycnostads to examine their formation and circulation.

\section{T/S RELATIONSHIPS FOR NACW}

Scatter plots of $\theta / \mathrm{S}$ for all SeaSoar data along each of the 6 meridional lines are shown in Fig. 5 along with a reference line, which we compare with other $\theta / \mathrm{S}$ reference lines in 
Fig. 6 and Table 1. Data from the seasonal thermocline and mixed layer are included in Fig. 5, and cause the scatter at temperatures above the reference line, but the plot is dominated by the large number of points close to Central Water curves. The extended, latitudinal coverage of each plot $\left(15^{\circ}\right.$ for $\mathrm{W}, \mathrm{X}, \mathrm{Y}$ and $\left.\mathrm{Z}\right)$ and limited vertical coverage $(0-500 \mathrm{~m})$ accentuates the well-proven concept that the $\theta / \mathrm{S}$ relationship of Central Waters is closely related to their formation by winter mixing in the surface layer along a wide range of latitudes (ISELIN, 1939). On line W, for example, points with temperatures above (below) say $10^{\circ} \mathrm{C}$ lie primarily south (north) of $48^{\circ} \mathrm{N}$, yet a straight line can be fitted from $8^{\circ} \mathrm{C}$ to $15^{\circ} \mathrm{C}$. The reference line we have chosen (Table 1) was fitted by eye to line $\mathrm{W}$ (Fig. 5) and is exactly linear from $16^{\circ} \mathrm{C}$ to $10^{\circ} \mathrm{C}$, curving gradually between $10^{\circ} \mathrm{C}$ and $6^{\circ} \mathrm{C}$. The same technique was used by HARVEY (1982) in his definition of ENAW but our line is more tightly constrained by the data (within 0.02 in salinity at constant temperature). We shall refer to it as the V91 (VIVALDI 1991) $\theta / S$ curve, to emphasize that it is appropriate for 1991, but not necessarily for other years. The significance of the V91 curve will be examined in the next section.

Across the whole survey area, Fig. 5 shows that the $\theta / \mathrm{S}$ relation becomes gradually more saline at any given temperature from west to east. The $\theta / \mathrm{S}$ curves tend to remain parallel to the V91 curve, but by $12^{\circ} \mathrm{W}$ (line B) they are about 0.08 more saline. In order to explore the relationship between fresher WNAW and more saline ENAW, we define the salinity anomaly as the excess, at a given temperature, of the salinity over the V91 value (Fig. 7). It is clear from Fig. 7 that there is considerable spatial structure in the salinity anomaly and hence in the Central Water masses. Even on line W, the anomaly ranges from -0.06 to +0.04 (ignoring the surface layer where the anomaly is very fresh and ignoring also the anomalously salty values north of $51^{\circ} \mathrm{N}$, which have temperatures less than $6^{\circ} \mathrm{C}$, compare Fig. 3a, and are not Central Waters). Between $43.5^{\circ} \mathrm{N}$ and $46.5^{\circ} \mathrm{N}$ on line $\mathrm{W}$ there are areas of anomalously saline water, and we note that the most saline patches are the pycnostads mentioned at the end of Section 2. We shall return to this important correlation in Section 3.2. Between $45.5^{\circ} \mathrm{N}$ and $48.5^{\circ} \mathrm{N}$ the water is mostly anomalously fresh. Both saline and fresh anomalies appear to be traceable to the east at least through lines $\mathrm{Y}$ and $\mathrm{Z}$.

\subsection{Comparison of $\theta / \mathrm{S}$ relationships}


First, however, let us establish the significance of the V91 $\theta / \mathrm{S}$ relation. Compare the positions of the southern and northern branches of the NAC on lines $\mathrm{W}, \mathrm{X}$ and $\mathrm{Y}$ (marked $\mathrm{S}$ and $\mathrm{N}$ on Fig. 3c) with the salinity anomalies in Fig. 7. On all three lines, the water between these two fronts has salinity anomalies from V91 of less than 0.02 (positive or negative) with temperatures (Fig. 3a) ranging from $11.5^{\circ} \mathrm{C}$ down to $7.5^{\circ} \mathrm{C}$. Thus V91 is the $\theta / \mathrm{S}$ relationship for WNAW flowing east in the NAC. At the southern end of line W, where $17 \mathrm{~Sv}$ flows eastward between W39 and W42 (Fig. 2), the salinity anomalies are again within 0.02 of $\mathrm{V} 91$, here with temperatures from $16^{\circ} \mathrm{C}$ down to $11.5^{\circ} \mathrm{C}$. Again, V91 is the $\theta / \mathrm{S}$ relationship for WNAW flowing southeast, possibly on the northern edge of the Azores Current.

The classical definition of WNAW is the $\theta / \mathrm{S}$ curve for North Atlantic Central Water given by ISELIN (1936) (he called it Central Atlantic Water) for the Sargasso Sea (Table 1 and Fig. 6). ISELIN (1936) separately discussed a section down $30^{\circ} \mathrm{W}$ from $52.5^{\circ} \mathrm{N}$ to $37^{\circ} \mathrm{N}$, taken on the first cruise of the Atlantisin 1931 . The $30^{\circ} \mathrm{W}$ section lies close to line W, from which V91 is defined, and was taken 60 years earlier, so it is appropriate to use $30^{\circ} \mathrm{W}$, rather than Sargasso Sea WNAW, to compare with V91. The $\theta / \mathrm{S}$ relation changes along the 1931 section (ISELIN, 1936) becoming more saline to the south, so the values we have extracted in Table 1 and plotted in Fig. 6 (labelled 131, ISELIN 1931, by comparison with V91) come from Atlantis stations 1004-1007, where the main NAC flow was concentrated.

The differences between classical WNAW and 131, though small (Table 1), are, we believe, significant. Above $10^{\circ} \mathrm{C}, 131$ differs only slightly from the Sargasso Sea WNAW (Table 1), being no more than 0.03 more saline in the temperature range $14^{\circ} \mathrm{C}$ $11^{\circ} \mathrm{C}$. We suspect that the higher salinities of 131 relative to Iselin's WNAW are caused by slight influence of ENAW even at $30^{\circ} \mathrm{W}$, as will become apparent when we discuss the circulation in several density ranges (section 4). More significantly, 131 salinities below $10^{\circ} \mathrm{C}$ are fresher than WNAW by as much as 0.12 , reflecting the fact that by the time Sargasso Sea water reaches $30^{\circ} \mathrm{W}$ it has been freshened by the addition of SubArctic Intermediate Water (SAIW), as Iselin himself discussed. The reason why we prefer 131 to WNAW for comparison with V91 is that I31 is more weighted to the upper layers at temperatures below $10^{\circ} \mathrm{C}$, so matches V91 in both location (NAC) and depth (0-500 m). 
At low temperatures the V91 $\theta / \mathrm{S}$ curve enters the diamond (Fig. 6) which defines SAIW (HARVEY and ARHAN, 1988), and water with SAIW characteristics is clearly apparent on lines W, X and Y (Fig. 5) north of the northern branch of the NAC (Fig. 3). Note in particular the salinity minimum (salinities less than 34.9) on Fig. 3b, confirming than Front $\mathrm{N}$ is the southern limit of outcropping SAIW (SY, 1988). It is noteworthy that the dense scatter of SAIW points apparent in SeaSoar data (Fig. 5) is not mirrored in the $\theta / \mathrm{S}$ scatter plots from the full-depth CTDs (Fig. 8). While SAIW is present in the upper $500 \mathrm{~m}$ in sufficient quantity to provide the low salinity endpoint for the V91 Mode Water $\theta / \mathrm{S}$ curve, the CTD data confirm that the low salinities are quickly mixed away once SAIW subducts beneath the NAC, as first noted by ISELIN (1936) and more recently by ARHAN (1990). Indeed, SAIW is not itself a Mode Water formed by convective processes (ARHAN, 1990), but "issues directly from the western boundary current of the subpolar gyre." In support of this statement, the lowest salinities in Fig. 8 in the temperature range $4^{\circ} \mathrm{C}-7^{\circ} \mathrm{C}$ all come from CTD W51, where the flow in the northern branch of the NAC is strongly advecting water from the west. We may remark in passing that the freshest Labrador Sea Water (LSW) in Fig. 8, a distinct cluster of points around $3.3^{\circ} \mathrm{C}, 34.86$, also comes from W51, showing that LSW is also advected east in the NAC (CUNNINGHAM and HAINE, 1995a).

In summary, the last few paragraphs show that, at temperatures above $10^{\circ} \mathrm{C}$, the $\mathrm{NAC}$ carries unmodified WNAW eastwards. Below $10^{\circ} \mathrm{C}$, both V91 and $\mathrm{I} 31$ are fresher than WNAW, with nearly straight line $\theta / \mathrm{S}$ relations trending towards SAIW. The presence of this straight line relationship in the upper layer and SeaSoar data, but not in CTD data from underlying waters, shows that the $\theta / \mathrm{S}$ relationship is primarily created by horizontal mixing in the surface layers, probably caused by eddy transports interacting with horizontal Ekman transports.

Comparison of I31 with V91 (Table 1) shows that the two $\theta / \mathrm{S}$ curves are nearly parallel from $16^{\circ} \mathrm{C}$ down to $8^{\circ} \mathrm{C}$, being more saline by $0.05-0.08$ in 1991 than in 1931 . It is beyond the scope of this paper to consider the temporal progression of changes in WNAW carried by the NAC. We know that its characteristics do change (DICKSON, MEINCKE, MALMBERG and LEE, 1988), and examination of data presented by ARHAN (1990) and by SY, SCHAUER and MEINCKE (1992) from TOPOGULF in 
each of the years $1981,1982,1983$ and 1984 shows that the $\theta / S$ curve for the NAC was fresher than V91 throughout. It is sufficient for our purposes to argue that the water carried by the NAC is in all years no more saline than it was in 1991 (V91), so cannot be responsible for the more saline ENAW by advection alone.

Comparison of V91 with the $\theta / \mathrm{S}$ curve for ENAW (Fig. 6) derived first by HARVEY (1982) and extended to higher temperatures by RIOS, PEREZ and FRAGA (1992) leads us to conclude that their curve should not be used in general to define ENAW. In 1991, WNAW entering the eastern North Atlantic across the Mid-Atlantic Ridge in the NAC already had salinities as high as RIOS' ENAW for temperatures of $12-14^{\circ} \mathrm{C}$. In fact, a single curve representing ENAW is not possible, as it varies considerably in space (Fig. 7) and time (PEREZ, RIOS, KING and POLLARD, 1995), because of interannual changes in air-sea fluxes and the balance between advection and air-sea interaction to be discussed in this paper. We have however noted on Fig. 6 the maximum salinity curve for ENAW found during Vivaldi, which is $0.08-0.10$ more saline than V91.

\subsection{Using $\theta / \mathrm{S}$ relationships to deduce the circulation}

The area within which the absolute value of the salinity anomaly is smaller than 0.02 may be used to trace the path of the NAC northwards as well as eastwards. North of Front $\mathrm{N}$ on line $\mathrm{W}$, the Central Water (i.e. $\mathrm{T}>6^{\circ} \mathrm{C}$ ) is fresher than WNAW, showing SAIW influence (ARHAN, 1990). (For temperatures less than $6^{\circ} \mathrm{C}$, the $\theta / \mathrm{S}$ relation is highly variable, Fig. 5, and salinity anomalies are differences from an arbitrary constant value, Fig. 6.) Similarly, on lines $\mathrm{X}$ and $\mathrm{Y}$ the water north of Front $\mathrm{N}$ is slightly fresher than V91, with a significant volume in which the salinity anomaly lies between -0.04 and +0.02 . This is consistent with the NAC turning northwards as shown by our geostrophic transport calculations (Fig. 2). On line Y there is an eddy-like region between $52.8^{\circ} \mathrm{N}$ and $53.6^{\circ} \mathrm{N}$ in which temperatures are warmer than to the north, south and west (Fig. 3a), and where the salinity anomaly is less than +0.02 . This indicates V91 water from between the two NAC branches, so we have contoured the northern branch in Fig. 2 as turning northwards along line Y. By $20^{\circ} \mathrm{W}$ (line Z), the only latitudes for which the salinity anomaly is within 0.02 of V91 are from $50.2^{\circ} \mathrm{N}$ to $50.9^{\circ} \mathrm{N}$ and from $53.2^{\circ} \mathrm{N}$ to $53.8^{\circ} \mathrm{N}$ (Fig. 7). Thus the southern branch of the NAC has turned north 
at or just west of $20^{\circ} \mathrm{W}$, consistent with the circulation pattern developed by ELLETT (ELLETT and BLINDHEIM, 1992; ELLETT, EDWARDS and BOWERS, 1986).

This conclusion is substantiated by examining the west to east SeaSoar section along $54^{\circ} \mathrm{N}$ from Y54 to Z54 (Fig. 1), shown in Fig. 9. The "northern" (now western) branch of the NAC is clearly revealed at $23.6^{\circ} \mathrm{W}$ by a sudden increase (from west to east) in thickness between isopycnals 27.25 and $27.3 \mathrm{~kg} \mathrm{~m}^{-3}$ (Fig. 9c) and the salinity anomaly (Fig. 9d) lying between -0.02 and 0.00 from beneath the seasonal thermocline to a depth of over $250 \mathrm{~m}$. The "southern" (eastern) branch is marked at $21.7^{\circ} \mathrm{W}$ by an even sharper change in $\theta / \mathrm{S}$ properties, the salinity anomaly between about 150 and $350 \mathrm{~m}$ increasing from west to east by 0.08 in less than $10 \mathrm{~km}$. There is an associated change in the thickness between the 27.3 and $27.35 \mathrm{~kg} \mathrm{~m}^{-3}$ isopycnals. These features mark changes in water mass properties but do not tell us about velocities. However, the existence of two distinct frontal jets with northward velocities may be inferred from the two areas where isopycnals slope downwards from west to east, between $23^{\circ} \mathrm{W}$ and $24^{\circ} \mathrm{W}$ and between $21^{\circ} \mathrm{W}$ and $22.2^{\circ} \mathrm{W}$. Thus the NAC crosses $54^{\circ} \mathrm{N}$ primarily between $21^{\circ} \mathrm{W}$ and $24^{\circ} \mathrm{W}$, carrying about $10 \mathrm{~Sv}$ (Fig. 2, CTDs Y54 and Z54). The marked change in water mass (salinity anomaly) properties between lines Z and A (Fig. 7) and the sharp change at $54^{\circ} \mathrm{N}, 21.7^{\circ} \mathrm{W}$ (Fig. 9b) are evidence that the salinity of ENAW east of $20^{\circ} \mathrm{W}$ has been enhanced by a mechanism other than advection and mixing from the NAC.

South of the southern branch of the NAC, the Central Water is significantly more saline than V91 almost everywhere. The only exceptions are the southern end of line W (mentioned above) and a wedge of significantly fresher water between $45.7^{\circ} \mathrm{N}$ and $48.5^{\circ} \mathrm{N}$ on line $\mathrm{W}$ which appears to extend eastwards, thinning in latitudinal extent to line $\mathrm{Y}$, where a fresh anomaly is just visible at $47.8^{\circ} \mathrm{N}$. If this is a wedge of WNAW freshened by SAIW influence advecting eastwards across the mid-Atlantic Ridge, it penetrates no further than $25^{\circ} \mathrm{W}$ (line Y). However, centred on $49^{\circ} \mathrm{N}$, north of this fresh wedge and immediately south of the southern NAC front on lines X, Y and Z, we note that the water is anomalously saline. We shall argue that this is a result of westward penetration of ENAW along $49^{\circ} \mathrm{N}$.

Significantly, patches of high salinity anomaly relative to surrounding water correlate in nearly all cases with pycnostads, i.e. patches of water more weakly stratified than 
surrounding water. Examples are shown in Fig. 10. This correlation clearly favours the hypothesis that enhanced salinity of ENAW is caused by air-sea interaction (POLLARD and PU, 1985). Areas of weak stratification in most cases originate from deep winter mixing, and JENKINS (1982) has described the mechanism by which salinity on an isopycnal (or in our case isotherm) is enhanced. It is not that salinity itself has increased very much, although evaporation does contribute. The major cause is anomalously large winter cooling, which drops the temperature and increases the density beyond the values reached in the previous winter. It is the density which has changed, not the salinity. The Central Water $\theta / \mathrm{S}$ curve representing winter mixed layer values drops along its length to a lower temperature, so the salinity becomes larger for a given temperature. The effect has recently been modelled by NEW and BLECK (1995). The temporal development of the salinity anomalies in the northeast Atlantic between 1988 and 1991 are discussed in a companion paper (READ, POLLARD and KING, personal communication). Note that care must be taken in the interpretation of isopycnic properties in this case, as the density itself is changing. It is for this reason that we have preferred to define salinity anomalies (Fig. 7) at constant temperature rather than at constant density.

The conclusion that the enhanced salinity of ENAW derives from winter cooling is an important one, so let us examine whether the correlation between enhanced thickness and enhanced salinity anomaly holds everywhere. The correlation is convincingly shown (Fig. 10) by examining salinity anomalies (Fig. 7) wherever the separation between adjacent isopycnals (Fig. 3c) is anomalously large. Clear examples (line, latitude range, density range) are $\left(\mathrm{W}, 45-47^{\circ} \mathrm{N}, 27.00-27.05\right),\left(\mathrm{X}, 43.5-44.5^{\circ} \mathrm{N}, 26.95-\right.$ 27.05), (X, 48-50 $\left.{ }^{\circ} \mathrm{N}, 27.05-27.20\right)$, ( $\mathrm{Y}$ and $\left.\mathrm{Z}, 39-41^{\circ} \mathrm{N}, 26.90-27.00\right)$, ( $\mathrm{Y}$ and $\mathrm{Z}, 41.5-$ $\left.47^{\circ} \mathrm{N}, 27.05-27.15\right),\left(\mathrm{Y}, 48-49.5^{\circ} \mathrm{N}, 27.15-27.25\right),\left(\mathrm{Z}, 49-50^{\circ} \mathrm{N}, 27.15-27.20\right)$, and most of lines A and B. This list covers a wide range of densities $\left(26.90-27.25 \mathrm{~kg} \mathrm{~m}^{-3}\right)$ and latitudes $\left(39-50^{\circ} \mathrm{N}\right)$. Notably, it does not cover the pycnostads in the NAC itself, between Fronts $\mathrm{S}$ and $\mathrm{N}$ on Fig. 3c, densities 27.2-27.3 $\mathrm{kg} \mathrm{m}^{-3}$, for which the $\theta / \mathrm{S}$ relation is, if anything, fresher than for waters to the south. Isopycnals in this density range drop rapidly below $500 \mathrm{~m}$ at the southern NAC front, so cannot be easily followed from SeaSoar data alone. However, examination of $\theta / S$ profiles south of the NAC from CTDs (Fig. 8) tend to show increasing salinity because of the influence of Mediterranean Water. 
In summary, Vivaldi 1991 evidence is that ENAW forming in the survey area south and east of the NAC has had its salinity anomaly at constant temperature increased by winter cooling. There is no evidence for enhanced salinities in the weakly stratified water entering the survey region from the west in the NAC. We infer that advection in the NAC is sufficiently rapid that SAIW influence there dominates over local winter cooling.

\section{PYCNOSTADS}

We now examine the circulation in more detail by examining several pycnostads separately, using the information that areas of weak stratification and positive salinity anomaly originated from winter Mode Water formation. The reader should refer primarily to the salinity anomaly Fig. 7, to which isopycnals taken from Fig. 3c have been added, but cross-reference to Figs 3 and 10 will also be helpful. We begin with the pycnostad which contains the largest volume of Mode Water, and which also is contained within the Vivaldi survey area. The units of density $\left(\mathrm{kg} \mathrm{m}^{-3}\right)$ will mostly be omitted, for brevity.

\subsection{Density range $27.05-27.15$}

In this density range (the two lightest shades of green in Fig. 3c), temperatures mostly lie between $11.5^{\circ} \mathrm{C}$ and $12.5^{\circ} \mathrm{C}$ (Fig. 3a). On lines $\mathrm{Y}, \mathrm{Z}$ and $\mathrm{B}$ this pycnostad is dominant between $42^{\circ} \mathrm{N}$ and $47^{\circ} \mathrm{N}$, occupying much of the SeaSoar depth range 0-500 $\mathrm{m}$. On line A it is prevalent in the same latitude band, but confined to the upper $250 \mathrm{~m}$. West of line $Y$ the strength of the stad decreases considerably, i.e. the stratification increases, and it is mostly found deeper than $250 \mathrm{~m}$. An exception is line X, along which stratification is weakest around $49^{\circ} \mathrm{N}$, just south of the southern branch of the NAC.

Clearly, this stad is not advecting in from the north or west. Nor can it enter the survey region from the south, as the isopycnals deepen south of $42^{\circ} \mathrm{N}$ on lines $\mathrm{Y}$ and $\mathrm{Z}$ and south of $43^{\circ} \mathrm{N}$ on line $\mathrm{B}$, and stratification increases. An explanation consistent with both Fig. 3 and the circulation of Fig. 2 is that Mode Water with densities around 27.1 forms in large quantities between the Iberian coast and about $20^{\circ} \mathrm{W}$, remaining for the 
most part in that region as it circulates anticyclonically around $45^{\circ} \mathrm{N}, 16^{\circ} \mathrm{W}$. The denser water along line A compared with both lines $\mathrm{Z}$ and $\mathrm{B}$ is consistent with such a circulation, with a tendency to southward flow between lines A and B and northward flow along $20^{\circ} \mathrm{W}$ (Fig. 2). Clues to the rates of circulation and the rates and direction of ventilation of this stad may be gleaned from its salinity anomaly and from measurements of the tracer CFC-113 taken from the Vivaldi CTD casts (HAINE, WATSON and LIDDICOAT, 1995). The density and salinity anomaly of the Mode Waters are both larger on lines $\mathrm{A}$ and $\mathrm{B}$ than on line $\mathrm{Z}$ and also larger than in previous years (READ, POLLARD and KING, personal communication), indicating that denser water created in winter $1990-91$ has barely reached $20^{\circ} \mathrm{W}$. On line Z, the largest salinity anomalies lie between $42^{\circ} \mathrm{N}$ and $44^{\circ} \mathrm{N}$, consistent with westward flow. Indeed, there is little evidence for the southward ventilation that is widely assumed following MCCARTNEY and TALLEY (1982). A sharp southern boundary to the stad is apparent in its salinity anomaly and thickness. In Fig. 4 , the $12.0-12.4^{\circ} \mathrm{C}$ thermostad (shaded) comes to an abrupt end at $42.6^{\circ} \mathrm{N}$ on line $\mathrm{B}$ and at $40.9^{\circ} \mathrm{N}$ on line $\mathrm{Z}$. At that same latitude on line $\mathrm{Z}$ the salinity anomaly on 27.1 decreases southwards from 0.06 to less than 0.02 at $40.2^{\circ} \mathrm{N}$. Similar, though weaker, changes are apparent on line Y. These changes all indicate a sharp change in water mass properties from north to south.

HAINE, WATSON and LIDDICOAT (1995) determine remarkably large ventilation ages of 9-13 years at $\mathrm{Y} 39$ and $\mathrm{Z} 39$ on the 27.1 isopycnal, reducing to 4-6 years at $\mathrm{Y} 42$, Y45, Z42 and B42 (from data in their Figs 7b and 8). At the other stations for which they had data, Z45, Z48, A42 and A48, the water was recently formed. The contouring of HAINE, WATSON and LIDDICOAT (1995) in their Fig. 7, though somewhat imaginative where there are no data, supports the anticyclonic circulation around A42 with westwards to northwestwards ventilation across $20^{\circ} \mathrm{W}$. Let us compare their findings carefully with ours.

On line $\mathrm{B}$, the 27.1 isopycnal outcropped at $43^{\circ} \mathrm{N}$, only $1^{\circ}$ north of $\mathrm{B} 42$, where a ventilation age of 6 years was calculated at a depth of $250 \mathrm{~m}$. In previous years (READ, POLLARD and KING, personal communication) 27.1 outcropped several degrees further north. Thus water of density 27.1 at B42 may have travelled several degrees southwards (but no more) in the years since its ventilation. In winter 1990/91, however, the mixing which reached possibly 
$300-400 \mathrm{~m}$ deep at $43^{\circ} \mathrm{N}$ (Fig. 3c, line B) cannot have reached $250 \mathrm{~m}$ at $42 \mathrm{~N}$. However, we feel that the ages of HAINE, WATSON and LIDDICOAT (1995) must be treated with caution, as the salinity anomaly at B42 (Fig. 7) is greater than 0.06, which in our interpretation suggests recent (previous winter) ventilation. On line Z, likewise, Z42 lies close to the southern limit of Mode Water (Fig. 3c and Fig. 4) reaching to over $250 \mathrm{~m}$ deep. Nevertheless, the large increase in ventilation age from 4 years to 10 years or so from $42^{\circ} \mathrm{N}$ to $39^{\circ} \mathrm{N}$ on lines $\mathrm{Y}$ and $\mathrm{Z}$ strengthens the argument that there is little southward ventilation.

There are two ways in which this conclusion can be reconciled with the southward ventilation discussed by MCCARTNEY and TALLEY (1982) and the numerous earlier authors whom they reference. One is that the circulation pattern in recent years is different from what was apparent in the historical data they described. The other is that the pycnostad ventilation path is more contorted than previously appreciated, running westwards at around $40^{\circ} \mathrm{N}$, but curving back to the south and east somewhere in the vicinity of the Azores. We have already noted in section 2.1 the evidence that westward flow across $20^{\circ} \mathrm{W}$ between $40^{\circ} \mathrm{N}$ and $45^{\circ} \mathrm{N}$ is not a new phenomenon, so we are reluctant to invoke temporal changes in circulation. Also MCCARTNEY and TALLEY (1982), comparing zonal sections along $32^{\circ} \mathrm{N}, 36^{\circ} \mathrm{N}, 40^{\circ} \mathrm{N}, 43^{\circ} \mathrm{N}, 46^{\circ} \mathrm{N}$ and $48^{\circ} \mathrm{N}$, remark that "in the northern four sections the pycnostad is strong, at $36^{\circ} \mathrm{N}$ it is noticeably weaker, and at $32^{\circ} \mathrm{N}$ it is barely discernable." This is consistent with a contorted path carrying the stad from $40^{\circ} \mathrm{N}$ to $36^{\circ} \mathrm{N}$, so that the water at $36^{\circ} \mathrm{N}$ is considerably older and the weaker stratification largely mixed away. So a contorted path seems the more likely explanation. Despite the 10 year ventilation ages at $39^{\circ} \mathrm{N}$, there is a noticeable thermostad (Fig. 3a) for $11.5^{\circ} \mathrm{C}<\mathrm{T}<12.5^{\circ} \mathrm{C}$ on lines $\mathrm{X}, \mathrm{Y}$ and $\mathrm{Z}$ (but not W) extending southwards to $39^{\circ} \mathrm{N}$ compared to the immediately overlying water, which is evidence for weak southwards ventilation. Recent results from an eddy-resolving Atlantic Isopycnic Model (A. NEW, personal communication) support this circulation pattern.

Finally, we note that enhanced thickness of the 27.05-27.15 density range is still apparent along parts of lines $\mathrm{W}$ (between $44^{\circ} \mathrm{N}$ and $46^{\circ} \mathrm{N}$ ) and $\mathrm{X}$ (between $40^{\circ} \mathrm{N}$ and $45^{\circ} \mathrm{N}$ ). There is a positive salinity anomaly in these regions also, so that westward ventilation as far as $45^{\circ} \mathrm{N}$, 
$30^{\circ} \mathrm{W}$ is indicated, as we shall discuss further in the next section (4.2) where we describe the lighter stad which overlies the stad presently under discussion. On line X, the most weakly stratified region for this stad is centred on $49^{\circ} \mathrm{N}$, where it occupies the upper $400 \mathrm{~m}$. We shall discuss this further in section 4.4 .

\subsection{Density range $27.00-27.05$}

The area within which this pycnostad appears to have been formed recently by winter mixing lies round the southern and western edge of the $27.05<\sigma_{0}<27.15$ pycnostad discussed in 4.1 . Temperatures in this density range are typically between $12.5^{\circ} \mathrm{C}$ and $13.0^{\circ} \mathrm{C}$. It is helpful to examine surface salinities in the range $35.8<\mathrm{S}<35.9$ (shaded orange in Fig. 3b). This pycnostad is most prevalent immediately below the seasonal mixed layer along line $\mathrm{Y}$ between $42^{\circ} \mathrm{N}$ and $46.5^{\circ} \mathrm{N}$, but it is also seen on lines $\mathrm{W}$ and $\mathrm{X}$ between $45^{\circ} \mathrm{N}$ and $46^{\circ} \mathrm{N}$, line $\mathrm{Z}$ between $41^{\circ} \mathrm{N}$ and $42^{\circ} \mathrm{N}$ and at $46^{\circ} \mathrm{N}$ and line $\mathrm{B}$ between $42^{\circ} \mathrm{N}$ and $43^{\circ} \mathrm{N}$. Several of these regions are also highlighted by the thermostad with $12.8^{\circ} \mathrm{C}<\theta<13.2^{\circ} \mathrm{C}$ that is lightly shaded in Fig. 4, lines $\mathrm{W}, \mathrm{Z}$ and B. All these regions have positive salinity anomalies at least as large as 0.04 .

However, this pycnostad is also found subducted on lines $\mathrm{W}\left(43^{\circ} \mathrm{N}-43.5^{\circ} \mathrm{N}\right.$ and $46^{\circ} \mathrm{N}-$ $\left.46.5^{\circ} \mathrm{N}\right)$ and $X\left(43^{\circ} \mathrm{N}-44.5^{\circ} \mathrm{N}\right)$, so there are two possible explanations why this pycnostad is found on lines $\mathrm{W}$ and $\mathrm{X}$ west of $24^{\circ} \mathrm{W}$. It could have formed by winter convection at those longitudes or it could have advected westwards from the vicinity of $24^{\circ} \mathrm{W}$ along line $\mathrm{Y}$. There is some evidence for the advective explanation. Isopycnals slope upwards to the south from $46^{\circ} \mathrm{N}$ to $44^{\circ} \mathrm{N}$ on line $\mathrm{W}$, so that the baroclinic flow becomes more westward in the surface layer. The salinity anomalies on line $\mathrm{W}$ are largest in this same latitude band. The same is true (upward sloping isopycnals, largest salinity anomaly) on line $\mathrm{X}$ between latitudes $44^{\circ} \mathrm{N}$ and $43^{\circ} \mathrm{N}$. On line $\mathrm{X}$ too this pycnostad lies beneath a lighter pycnostad (section 4.3) and the salinity anomaly extends downwards through them both, again indicative of westward flow.

It is interesting that, on lines $\mathrm{Y}$ and $\mathrm{Z}$, south of $41^{\circ} \mathrm{N}$, the salinity anomaly for this pycnostad is weaker than for both lighter, overlying (section 4.3) and heavier, underlying (section 4.1) water. This will be discussed in section 5 . 
While water with densities less than $27.00 \mathrm{~kg} \mathrm{~m}^{-3}$ (shades of dark green and blue in Fig. $3 c$ ) is prevalent in the southwest corner of the Vivaldi survey area, there are only a few places where the separation of isopycnals just beneath the seasonal thermocline suggests stads created by winter mixing. There is no evidence for stads at the southern ends of lines $\mathrm{W}$ and $\mathrm{X}$. On lines $\mathrm{Y}$ and $\mathrm{Z}$, however, water with densities $26.9<\sigma_{0}<27.0$ is weakly stratified south of $41^{\circ} \mathrm{N}-41.5^{\circ} \mathrm{N}$ and on line $\mathrm{X}$ water with densities $26.95<\sigma_{0}<$ 27.0 between latitudes $43^{\circ} \mathrm{N}$ and $44^{\circ} \mathrm{N}$ (compare 4.2) is also weakly stratified. The large (greater than 0.04 ) salinity anomalies at the southern ends of lines $\mathrm{Y}$ and $\mathrm{Z}$ (which are absent on lines $\mathrm{W}$ and $\mathrm{X}$ ) are particularly noteworthy. They indicate that the anomalous cooling which has created the anomaly is present as far south as these latitudes $\left(39^{\circ} \mathrm{N}\right.$ $42^{\circ} \mathrm{N}$ ). Here however winter mixed layer depths are no deeper than about $250 \mathrm{~m}$ so the anomaly is only found above that depth.

RIOS, PEREZ and FRAGA (1992) distinguish between two types of ENAW, ENAW of subtropical origin, with temperatures greater than $12.2^{\circ} \mathrm{C}$ and $\mathrm{ENAW}_{\mathrm{p}}$ of subpolar origin, with temperatures lower than $12.2^{\circ} \mathrm{C}$. Following FRAGA, MOURIÑO and MANRIQUEZ (1982), they argue that the subpolar and subtropical varieties of ENAW tend to flow southwards and northwards respectively close to the Galician coast, meeting at a front in the vicinity of Cape Finisterre $\left(43^{\circ} \mathrm{N}\right)$. Using the Vivaldi data set, we can confirm and extend this interpretation. The pycnostad we are currently describing, $\sigma_{0}<27.00, \theta>13^{\circ} \mathrm{C}$ is clearly ENAW $\mathrm{T}$. It is forming, and gaining its salinity anomaly, south of $42^{\circ} \mathrm{N}$. It does not flow northwards across that latitude (Fig. 2), but can possibly flow westwards or northwestwards from line Y towards line W. The density range $27.00<\sigma_{0}<27.05$ (section 4.2 ) also has temperatures of $12.5^{\circ} \mathrm{C}-13.0^{\circ} \mathrm{C}$, so is ENAW T $_{\mathrm{T}}$ RIOS, PEREZ and FRAGA' s (1992) definition. From the discussion on advection in 4.2, we are suggesting that the positive salinity anomalies on lines $\mathrm{W}$ and $\mathrm{X}$, while partially caused by local Mode Water formation, are also caused by northwestward advection of ENAW $\mathrm{T}_{\mathrm{T}}$ on the southwestern flank of the anticyclonic circulation of ENAW (section 4.1) which is prevalent in our survey area north of $42^{\circ} \mathrm{N}$ and east of $24^{\circ} \mathrm{W}$ (line $\mathrm{Y}$ ). 
It is salutary, and rather chastening, to note that the circulation that we have derived is remarkably close to that envisaged by HELLAND-HANSEN and NANSEN (1926) (their Fig. 15, reproduced by ISELIN (1936), Fig. 48) from considerably sparser data! Their classic diagram shows an anticyclonic circulation north of a cyclonic circulation with westward flow between the two just north of $40^{\circ} \mathrm{N}$. This is further evidence that temporal change is not the explanation for the apparent paradox discussed at the end of section 4.1.

\subsection{Density range $27.15-27.20$}

Sections 4.1 through 4.3 dealt with successively lighter density ranges, so shallower layers. Now we progress to heavier values and deeper surfaces. Pycnostads in this density range (greenish yellow in Fig. 3c) are found south of $48^{\circ} \mathrm{N}$ on line $\mathrm{B}\left(45^{\circ} \mathrm{N}\right.$ $48^{\circ} \mathrm{N}$ ) and from $200-500 \mathrm{~m}$ deep on line A. Temperatures in these areas are mostly $11.5^{\circ} \mathrm{C}-12.0^{\circ} \mathrm{C}$, and the stad is simply a slightly denser northward extension of the major stad described in 4.1 .

However, there is also a westward extending stad in this density range, apparent on lines $\mathrm{X}, \mathrm{Y}, \mathrm{Z}$ and $\mathrm{A}$ north of $47^{\circ} \mathrm{N}-48^{\circ} \mathrm{N}$, which is less easy to explain. In addition to the southern and northern branches of the NAC, there is a third distinct density front (Fig. 3c) (which we named Front 3 in section 2.2) running west from $47.8^{\circ} \mathrm{N}$ on line $\mathrm{A}$, through $47.5^{\circ} \mathrm{N}$ (line Z) to $47.0^{\circ} \mathrm{N}$ (line $\mathrm{Y}$ ) and possibly even to $45.5^{\circ} \mathrm{N}$ on line $\mathrm{X}$. North of Front 3 and south of the southern NAC front (Front S) is the 27.15-27.20 pycnostad. We note that on the survey lines $\mathrm{X}, \mathrm{Y}$ and $\mathrm{Z}$ isopycnals slope up to the south between Fronts 3 and S, indicating westward baroclinic shear of the upper layer relative to underlying layers (compare 4.2). But salinity anomalies for this stad vary rapidly from south to north along each survey line and from east to west.

Immediately north of Front 3 , the salinity anomaly decreases westwards from 0.06-0.08 on line A through 0.02-0.04 (line Z), 0.00-0.02 (line Y) to less than zero on line X. Isopycnal slopes are weak, and we conclude that there is minimal advection and gradual mixing between WNAW (line X) and ENAW (line A). Note too that on all these lines the salinity anomaly is significantly smaller immediately north of Front 3 than 
immediately south of it, so the anticyclonic circulation carrying saline ENAW (section 4.1) has a sharp northern boundary at Front 3.

Further north in the stad, and immediately south of Front $\mathrm{S}$, the salinity anomaly is greater, though that too diminishes westwards from $0.06-0.08$ on line $\mathrm{Z}$ through 0.02 0.04 on line $\mathrm{Y}$ to $0.00-0.02$ on line $\mathrm{X}$. The most striking features here are the deep stads within what appear to be anticyclonic eddies. On line $\mathrm{Z}$, between $49.3^{\circ} \mathrm{N}$ and $50^{\circ} \mathrm{N}$, the temperature drops by less than $0.5^{\circ} \mathrm{C}\left(11.5^{\circ} \mathrm{C}\right.$ to $\left.11.0^{\circ} \mathrm{C}\right)$ from $50 \mathrm{~m}$ to $500 \mathrm{~m}$ and the salinity varies by less than 0.1 from the surface to $500 \mathrm{~m}$. Isopycnals rise both northwards and southwards from the centre of the eddy. The salinity anomaly in its core (about $60 \mathrm{~km}$ diameter) is greater than 0.06. A weaker but larger feature is apparent on line $\mathrm{Y}$ between $48^{\circ} \mathrm{N}$ and $49.2^{\circ} \mathrm{N}$. On line $\mathrm{X}$ the anticyclonic feature is again larger, spanning over $100 \mathrm{~km}$ from $48.5^{\circ} \mathrm{N}$ to $49.7^{\circ} \mathrm{N}$, and lighter, so was mentioned in 4.1 . There is no equivalent feature on line $\mathrm{W}$.

The weak stratification and positive salinity anomaly within these eddies clearly identifies them as ENAW formed by winter mixing. With our hydrographic data we cannot answer the obvious question, are the eddies propagating westwards or are they stationary? Indeed, it may be misleading to characterise these features as individual eddies. If the westward flows on the southern sides of these anticyclonic features can be connected, then there is a return circulation reminiscent of the return circulations near the Gulf Stream described by HOGG $(1992,1993)$.

\subsection{Density range $27.20-27.30$}

In this density range (yellow on Fig. 3c), there are again two distinct kinds of pycnostad. The first pycnostad is seen on lines $\mathrm{Z}$ and $\mathrm{A}$, with temperatures in the range $10^{\circ}-11^{\circ} \mathrm{C}$ and salinities in the range $35.4-35.5$. It extends through much of the depth range $100 \mathrm{~m}-500 \mathrm{~m}$ north of $50^{\circ} \mathrm{N}$, indicating that winter Mode Water near the entrance to the Rockall Trough (Fig. 1) forms in this density range. A second stad is apparent on lines $\mathrm{W}, \mathrm{X}$ and $\mathrm{Y}$, in the NAC between Fronts $\mathrm{S}$ and N, extending down to $400 \mathrm{~m}-500$ $\mathrm{m}$. It is colder, $9^{\circ}-10^{\circ} \mathrm{C}$, than the first stad and fresher, 35.2-35.4. As we shall now show, the salinity anomaly characteristics of these pycnostads are quite different from those described above, as are their formation mechanisms. 
Consider first the Mode Water near the entrance to the Rockall Trough. Temperatures on line A north of $49^{\circ} \mathrm{N}$ are no lower than $8.5^{\circ} \mathrm{C}$, and are mostly $10.5^{\circ} \mathrm{C}-11.0^{\circ} \mathrm{C}$. The $\theta /$ S scatter plot (Fig. 5) looks like ENAW over the entire temperature range, with no obvious hint of Mediterranean Water (MW) or SAIW influence at the lower temperatures. Yet the salinity anomaly displays two new characteristics. It reaches larger values (greater than 0.10 ) than for any of the density ranges so far described (marked on Fig. $6,10^{\circ} \mathrm{C}-11^{\circ} \mathrm{C}$ ), and it increases downwards. Downward increase has been noted before, but only in a few places where there has been weak subduction of saline ENAW. In the present density range it is much more marked, For example, on line $\mathrm{A}$, at $51.5^{\circ} \mathrm{N}$ say, the salinity anomaly increases from 0.06 at a depth of $50 \mathrm{~m}$ to over 0.10 at $250 \mathrm{~m}$. Close examination of the $\theta / \mathrm{S}$ curves (closer than is possible using Figs 5 and 8) reveals a zig-zag pattern with a series of short $\theta / \mathrm{S}$ segments parallel to the V91 curve, stepping sharply with depth to a greater offset. Details of the mixing process will be described in a separate paper in preparation. Here our concern is to identify the deep source of more saline water.

Winter mixing at the entrance to the Rockall Trough can be very deep, $500 \mathrm{~m}$ and more (MEINCKE, 1986), so we could invoke mixing with Mediterranean Water, which is apparent in Fig. 8 for densities greater than $27.20 \mathrm{~kg} \mathrm{~m}^{-3}$. However, Fig. 8 shows that admixtures of Central Water and LSW could also cause the salinity anomaly to increase with depth. Salinity decreases downwards for the $\theta / \mathrm{S}$ traces between the two lines marked in Fig. 8, but the salinity anomaly increases with depth because the traces diverge from the V91 line. So we must examine the geographical distributions of MW and LSW more carefully.

The solid lines in Fig. 8 divide the $\theta / \mathrm{S}$ traces into three regimes. Traces between the two lines show no clear preference for high (MW) or low (SAIW) salinities, and these traces come from CTDs W42, W45, X45, Z48 (above $7^{\circ} \mathrm{C}$ ), Z51 (wider scatter), Z54 and A54 (wider scatter). On line Y, Y45 is saltier, Y48 is fresher than these median traces. From Fig. 2, these traces all fall approximately along the $25 \mathrm{~Sv}$ contour. Thus the three regimes are: (1) in and northwest of the NAC, SAIW intrudes at intermediate depths between NACW and LSW, freshening the $\theta / \mathrm{S}$ traces; (2) MW influence increases strongly to the southeast, again intruding between NACW and LSW (though LSW itself 
weakens to the southeast); (3) in a narrow band no more than $3^{\circ}$ of latitude wide between SAIW influence and MW influence, there is a zone within which neither can be said to dominate. However, the $\theta / S$ traces in zone 3 do not fall along a straight line between NACW and LSW, having inflection points between 5 and $6^{\circ} \mathrm{C}$ and between 8 and $9^{\circ} \mathrm{C}$. The lower inflection point (towards higher salinity) hints at MW influence, and the upper infection point (fresher) reflects SAIW influence on the NACW.

The situation is most complex at the entrance to the Rockall Trough, which lies in zone 3. The inflection point towards higher salinity (at about $5.5^{\circ} \mathrm{C}, 35.07$ ) must be caused by MW influence and lies above LSW. The downward increase in salinity anomaly must therefore be MW influence, but it is surprisingly shallow. The depth of maximum MW influence along line A, from the oxygen minimum (GRIFFITHS, CUNNINGHAM, GRIFFITHS, POLLARD, LEACH, HOLLEY, PAYLOR, HAINE, RIOS, ALDERSON, LOWRY, SMITH, PRESTON, GWILLIAM, SMITHERS, KEENE, HEMMINGS and ANDERSON, 1992), is around $1000 \mathrm{~m}$, rising to $800-900 \mathrm{~m}$ at its northern end. But MW influence can be seen in $\theta / \mathrm{S}$ profiles $200-300 \mathrm{~m}$ above that maximum, so can just reach $500 \mathrm{~m}$. Thus a combination ofisopycnals rising to the north and deep mixing at the entrance to the Rockall Trough allows MW salinities to increase Central Water salinities in that region. The most saline varieties of ENAW have therefore had their salinities enhanced both from above (winter cooling) and below (mixing with MW), which results in $\theta / \mathrm{S}$ curves parallel to those for WNAW but about 0.1 more saline.

Now consider the pycnostad in the 27.2-27.3 density range lying just south of the northern front of the NAC. On line W this is the most weakly stratified stad along the whole line. On lines W, X, Y and Z this is the only stad which does not have a positive salinity anomaly relative to surrounding water in the same density range. It lies within 0.02 of the V91 $\theta / \mathrm{S}$ curve, with temperatures $8.0^{\circ} \mathrm{C}-9.5^{\circ} \mathrm{C}$ and salinities $35.1-35.3$. There is little that can be said about this stad from Vivaldi data alone. From the properties just noted, it is not forming by winter mixing in the Vivaldi survey area, but is advected into the area in the NAC. Its $\theta / \mathrm{S}$ properties change a little downstream as it mixes with surrounding water. Presumably, it is a Mode Water formed in the western North Atlantic, and advected sufficiently fast through our survey area that it is little 
further modified by air-sea interaction. Further investigation is beyond the geographical scope of this paper.

\subsection{Densities greater than 27.30}

Densities greater than $27.3 \mathrm{~kg} \mathrm{~m}^{-3}$ (shades of orange and red in Fig. 3c) are only found shallower than $500 \mathrm{~m}$ beneath and north of the NAC. For such densities, temperatures are mostly less than $8^{\circ} \mathrm{C}$ and salinities less than 35.00 on lines $\mathrm{W}, \mathrm{X}$ and $\mathrm{Y}$, indicating strong SAIW influence. Slightly higher values $\left(8.5^{\circ} \mathrm{C}, 35.10\right)$ are found in the eddy north of $53^{\circ} \mathrm{N}$ on line Y, where warmer Central Water has mixed with the SAIW. The one thing we can deduce about the circulation from examining this density range is that SAIW in the upper layers recirculates northwards to the west of the northern branch of the NAC. The salinity minimum found north of Front $\mathrm{N}$ is also confined west of that front $\left(23.6^{\circ} \mathrm{W}\right)$ where it turns northwards and crosses $54^{\circ} \mathrm{N}$ (Fig. 9b). The influence of subducted SAIW can be seen in $0 / \mathrm{S}$ curves from CTDs south and east of the NAC (Fig. 8 ) by intermediate salinity minima of $34.95-35.0,6^{\circ} \mathrm{C}-7^{\circ} \mathrm{C}$, saltier and warmer than the "diamond" definition of SAIW (Fig. 6) which come from the CTD casts at W48, X48, Y48 and Z51.

\section{DISCUSSION}

Examination of the circulation in several density intervals has shown that the major flow of Central Water across the mid-Atlantic Ridge into the Vivaldi survey region takes place between the northern and southern fronts of the NAC and that all of this transport recirculates to the north. South of the NAC, the variable salinity anomaly is caused by weak westward recirculation of more saline ENAW formed mostly east of $20^{\circ} \mathrm{W}$, interspersed along a south to north line with fresher WNAW penetrating slowly eastwards. ENAW can be traced as far west as line W around $45^{\circ} \mathrm{N}$, and WNAW can be traced (south of the NAC) as far east as line $\mathrm{Z}$ around $48^{\circ} \mathrm{N}$. This interpretation requires re-evaluation of the definitions of "pure" NACW introduced by HARVEY and ARHAN (1988) and hence "modified" NACW between the main branches of the NAC discussed in detail by ARHAN (1990). 
The terms "pure" and "modified" Central Water were introduced by HARVEY and ARHAN (1988) to describe meridional variations in the vicinity of the Mid-Atlantic Ridge, with "pure" characterizing the averaged $\theta / \mathrm{S}$ diagram of the TOPOGULF stations and "modified" the significantly fresher water they found between the two branches of the NAC [ARHAN, personal communication]. We have shown that the Central Water in the eastern basin south of the NAC is not "pure", but is a mixture of WNAW and ENAW, in proportions varying from west to east. We recommend that use of the word "pure" should be dropped in favour of the regional nomenclature, WNAW and ENAW as used in this paper.

Water in the NAC, here called V91, matches neither of these definitions. It is primarily WNAW, but is fresher below $10^{\circ} \mathrm{C}$ than WNAW because of the addition of SAIW from the Labrador Current. HARVEY and ARHAN (1988) and ARHAN (1990) refer to it as "modified NACW". However, a similar term, Modified North Atlantic Water (MNAW) is in common usage to describe water in the region of the Iceland Faroe Ridge (BECKER and HANSEN, 1988), so another term is desirable. Not wishing to introduce a new definition for what is basically WNAW, though freshened by SAIW below $10^{\circ} \mathrm{C}$, we shall simply refer to it as "freshened WNAW" in this discussion.

The term NACW is a generic term covering all three Central Water types described, WNAW, ENAW and freshened WNAW, with a range of $\theta / \mathrm{S}$ properties. These three types of NACW cannot always be distinguished by differences in their $\theta / \mathrm{S}$ properties, because they change from year to year, and it is this which has led to confusion between them. WNAW has the most stable properties for densities greater than $27.0 \mathrm{~kg} \mathrm{~m}^{-3}$ (JENKINS, 1982), because it occupies a large volume of the recirculating subtropical gyre, where it is found beneath the seasonal thermocline, and is the end product of ventilating Mode Waters (MCCARTNEY, 1982). WNAW lighter than $27.0 \mathrm{~kg} \mathrm{~m}^{-3}$ displays as much temporal variability as ENAW described here, and for identical reasons (JENKINS, 1982), but we are here concerned primarily with the denser values. ENAW is variable in its characteristics, because it is restricted to the anticyclonic gyre northeast of the Azores that we have described, is modified annually by winter convection, and subducts only weakly to the south in the vicinity of the Azores to influence the $\theta / \mathrm{S}$ characteristics of WNAW around $11-12^{\circ} \mathrm{C}$. The weak subduction of ENAW is probably related to the weakness of the wind stress curl in its formation 
region, which lies only just southeast of the line of zero wind stress curl (e.g. LEETMA and BUNKER, 1978), plotted on Fig. 12 of MCCARTNEY (1982). Freshened WNAW is only found in the NAC. Its $\theta / \mathrm{S}$ properties too are variable (Fig. 6, V91 v.131, also DICKSON, MEINCKE, MALMBERG and LEE, 1988) because of long term changes in the properties of its parent water masses, WNAW and SAIW.

Mixing between these three types of NACW must occur, because their $\theta / \mathrm{S}$ relationships are so similar, but is restricted to several geographic locations. WNAW mixes with water from the Labrador Current east of the Grand Banks to create freshened WNAW. Recirculation west of the mid-Atlantic Ridge (CLARKE, HILL, REINIGER and WARREN, 1980; MCCARTNEY and TALLEY, 1982) will therefore tend to freshen WNAW. North of the Azores we have found both WNAW and ENAW to the south of the NAC, so these water masses mix weakly there. Further north, freshened WNAW in the NAC can be further freshened by mixing with SAIW just north of the NAC. Mixing is primarily accomplished by the eddies which are clearly apparent in Fig. 3. For example, eddies of freshened WNAW overriding SAIW are found on Fig. $3 \mathrm{~b}$ centred at $50.5^{\circ} \mathrm{N}(\mathrm{W}), 51.2^{\circ} \mathrm{N}(\mathrm{X}), 52.4^{\circ} \mathrm{N}(\mathrm{X}), 50.7^{\circ} \mathrm{N}(\mathrm{Y}), 53.2^{\circ} \mathrm{N}(\mathrm{Y})$ and $53.4^{\circ} \mathrm{N}(\mathrm{Z})$.

There is strong mixing between NAC water and ENAW at the southern entrance to the Rockall Trough where the NAC turns to the north. Deep winter mixing in the same area and south of it increases the salinity anomaly of ENAW both by cooling and by entrainment of MW. ENAW was particularly salty in 1991. In other years, winter cooling will be weaker than average and mixing less deep. ENAW salinities will then tend to freshen back towards WNAW or freshened WNAW values, because of the strong mixing with advected NAC water, as occurred during the Great Salinity Anomaly (DICKSON, MEINCKE, MALMBERG and LEE, 1988). Central Water south of the NAC may also be freshened by southward Ekman transport of fresher surface water by the prevailing westerly winds (BAUER, LEACH and WOODS, 1991; LEACH, 1990). However, ENAW will always be more saline than WNAW because the small input of MW provides a bias. We see now that there is no conflict between the various hypotheses put forward to explain the salinity anomalies: air-sea interaction (POLLARD and PU, 1985; and this paper), advection round the subpolar gyre (DICKSON, MEINCKE, MALMBERG and LEE, 1988), downward pumping of salt beneath the NAC (ARHAN, 1990) and mixing with MW (e.g. ELLETT, EDWARDS 
and BOWERS, 1986; HARVEY, 1982 and this paper). All these mechanisms contribute, with different balances in different years and at different places.

Continuing our anticyclonic progress, ENAW can itself be subdivided into two varieties (RIOS, PEREZ and FRAGA, 1992), colder ENAW (subPolar) moving southwards west of Galicia (section 4.1) and warmer ENAW $_{\mathrm{T}}$ (subTropical) moving northwards between the Azores and Portugal (section 4.3). ENAW $_{\mathrm{p}}$ is the major Mode Water created east of $20^{\circ} \mathrm{W}$ and north of $40^{\circ} \mathrm{N}$ and circulating anticyclonically with temperatures less than $12.4^{\circ} \mathrm{C}$ (Fig. 4). ENAW $\mathrm{T}_{\mathrm{T}}$ we believe to be warmer $\left(>13^{\circ} \mathrm{C}\right)$ WNAW that flows east in the Azores Current then breaks off to the north (POLLARD and PU, 1985; RIOS, PEREZ and FRAGA, 1992). Both varieties of ENAW have their salinity modified by winter mixing, as can be seen in Fig. 7. At the southern end of line $\mathrm{Y}$ (and to a lesser extent line $\mathrm{Z}$ ), south of $41^{\circ} \mathrm{N}$, the salinity anomaly is large above 300 $\mathrm{m}\left(\mathrm{ENAW}_{\mathrm{T}}\right.$, densities less than $27.00 \mathrm{~kg} \mathrm{~m}^{-3}$ ), weak beneath that down to $400 \mathrm{~m}$, then increasing downwards $\left(\mathrm{ENAW}_{\mathrm{p}}\right.$, densities greater than $\left.27.10 \mathrm{~kg} \mathrm{~m}^{-3}\right)$. If the $\mathrm{ENAW}_{\mathrm{T}}$ is moving northwards towards $41^{\circ} \mathrm{N}$ and the ENAW is subducting (weakly) southwards at $41^{\circ} \mathrm{N}$, then the intermediate layer $(300 \mathrm{~m}-400 \mathrm{~m})$ is virtually stationary, so has acquired no salinity anomaly. Note that the temperature of the change-over between $\mathrm{ENAW}_{\mathrm{p}}$ and $\mathrm{ENAW}_{\mathrm{T}}$ that is found in Vivaldi is somewhat warmer $\left(12.5^{\circ} \mathrm{C}-13.0^{\circ} \mathrm{C}\right)$ than the $12.2^{\circ} \mathrm{C}$ used by RIOS, PEREZ and FRAGA (1992).

From the progression of the maximum salinity anomalies (Fig. 7) westward from line $Z$ at $43^{\circ} \mathrm{N}$ to line $\mathrm{W}$ at $45^{\circ} \mathrm{N}$, we have inferred that both $\mathrm{ENAW}_{\mathrm{T}}$ and $\mathrm{ENAW}_{\mathrm{p}}$ recirculate to the west in a pattern similar to that given by HELLAND-HANSEN and NANSEN (1926). But there is also evidence for a poleward eastern boundary current, particularly in satellite images (e.g. PINGREE and LE CANN, 1990). While we have no data on lines A and B south of $42^{\circ} \mathrm{N}$, a Spanish survey GALICIA XI which took place during Vivaldi (10-14 May, 1991) (CASTRO, PEREZ, ALVAREZ-SALGADO, ROSON and RIOS, 1994) extends the Vivaldi survey right up to the Galician coast. Careful examination of the $\theta / \mathrm{S}$ diagrams for all the GALICIA casts (CASTRO, PEREZ, ALVAREZ-SALGADO, ROSON and RIOS, 1994) shows that nearly all the Central Water temperatures lie in the range $11.5^{\circ} \mathrm{C}-12.5^{\circ} \mathrm{C}$ with $\theta / \mathrm{S}$ characteristics matching those on line $\mathrm{B}\left(43^{\circ} \mathrm{N}-45^{\circ} \mathrm{N}\right)$. Thus in spring $1991 \mathrm{NACW}$ right up to the coast has ENAW $\mathrm{p}_{\mathrm{p}}$ characteristics, and there is no evidence for $\mathrm{ENAW}_{\mathrm{T}}$ flowing north at that time. 
Finally, ENAW contributes to and modifies denser $\left(\sigma_{0}>27.0 \mathrm{~kg} \mathrm{~m}^{-3}\right)$ WNAW where it subducts in the region of the Azores. We have shown that there is little direct southward subduction east of $20^{\circ} \mathrm{W}$. Nevertheless, the weak pycnostads at $36^{\circ} \mathrm{N}$ and $32^{\circ} \mathrm{N}$ discussed by MCCARTNEY and TALLEY (1982) prove that there is Mode Water influence, and the Vivaldi data provide evidence for southward subduction west of $20^{\circ} \mathrm{W}$. ENAW will, over decades, tend to increase the salinity of WNAW by weak subduction. But that tendency is countered by freshening east of the Grand Banks, which is also weak, because of the lack of downward Ekman pumping north of the line of zero wind stress curl.

It is interesting to compare our description of the circulation with that of MCCARTNEY and TALLEY (1982). They describe the cyclonic circulation around the subpolar gyre, and the gradual cooling and freshening of Subpolar Mode Water from Central Water characteristics down ultimately to LSW. Modification in that cyclonic circulation is irreversible (LSW cannot revert to NACW) and caused by cooling right round the cyclonic path. We have concentrated on the anticyclonic circulation south of the NAC (also discussed by MCCARTNEY and TALLEY, 1982), but we have the major benefit of a wide area synoptic data set). The anticyclonic recirculation is quite different from the cyclonic. It is split into two gyres, the weakly circulating anticyclonic gyre northeast of the Azores and the subtropical gyre south of the Azores, joined only by weak subduction near the Azores. Water mass modification is reversible, in the sense that the water remains NACW, although its $\theta / \mathrm{S}$ characteristics fluctuate back and forth over many years. This is the case because the anticyclonic gyre is in a region of downward Ekman pumping allowing subduction, so that winter cooling is only possible in the northeast of the circulation region, and the changes induced by that cooling can be balanced by advection of fresher water by the NAC.

\section{ACKNOWLEDGEMENTS}

Many people contributed to the Vivaldi cruises. We would like to thank them all, and in particular the co-cruise leaders, Gwyn Griffiths and Harry Leach. The manuscript has been improved by numerous helpful comments from Michel Arhan, Harry Leach and an anonymous reviewer. 


\section{REFERENCES}

ARHAN, M. (1990) The North Atlantic Current and Subarctic Intermediate Water, Journal of Marine Research, 48, 109-144.

BAUER, J., H. LEACH and J.D. WOODS (1991) The summertime variation of heat and freshwater contents between the Azores and Greenland, Quarterly Journal of the Royal Meteorological Society, 117B, 1081-1104.

BOWERMAN, S.J. and H. LEACH (1996) Eddies in the North East Atlantic: Statistics from observations from a moving ship, Journal of Geophysical Research, (in press).

CASTRO, E.G., F.F. PEREZ, A. ALVAREZ-SALGADO, G. ROSON and A.F. RIOS (1994) Hydrographic conditions associated with the relaxation of an upwelling event off the Galician coast (NW Spain), Journal of Geophysical Research, 99, 5135-5147.

CLARKE, R.A., H.W. HILL, R.F. REINIGER and B.A. WARREN (1980) Current system south and east of the Grand Banks, Journal of Physical Oceanography, 10, 25-65.

CUNNINGHAM, S.A., M.J. GRIFF1THS, J. HEMMINGS, S.G. ALDERSON, G. GRIFFITHS, R.T. POLLARD, J.C. DONLAN, P. LANCASTER, H. LEACH, R.K. LOWRY, I.W. STIRLING, P. SMITH, T.J.P. GWILLIAM, J. SMITHERS, S. KEENE, R. PEARCE, T.R. ANDERSON, S. BOWERMAN and D.GROHMANN (1992) SeaSoar CTD, fluorescence and scalar irradiance data from RRS "Charles Darwin" Cruises 58/59, NE Atlantic (Vivaldi 91). Institute of Oceanographic Sciences Deacon Laboratory, Report No 299, 48 PP.

CUNNINGHAM, S.A. and T.W. HAINE (1995a) Labrador Sea Water in the eastern North Atlantic. Part I: A synoptic circulation inferred from a minimum in potential vorticity, Journal of Physical Oceanography, 25, 649-665.

CUNNINGHAM, S.A. and T.W. HAINE (1995b) Labrador Sea Water in the eastern

North Atlantic. Part II: Mixing dynamics and the advective-diffusive balance, Journal of Physical Oceanography, 25, 666-678.

DICKSON, R.R., J. MEINCKE, S.-A. MALMBERG and A.J. LEE (1988) The "Great Salinity Anomaly" in the northern North Atlantic 1968-1982, Progress in Oceanography, 20, 103-151. 
DIETRICH, G., K. KALLE, W. KRAUSS and G. SIEDLER (1975) Allgemeine Meereskunde, Bornträger, Berlin, 593 pp.

ELLETT, D.J. and J. BLINDHEIM (1992) Climate and hydrographic variability in the ICES area during the 1980s, ICES Marine Science Symposium, 195, 11-31.

ELLETT, D.J., A. EDWARDS and R. BOWERS (1986) The hydrography of the Rockall Channel - an overview. In: The Royal Society of Edinburgh, 88B, 61-81. FRAGA, F., C. MOURIÑO and M. MANRIQUEZ (1982) Las masas de agua en la costa de Galicia: junio-octubre, Resultados Expediciones Cientificas, 10, 51-77.

GRIFFITHS, G., S. CUNNINGHAM, I. GRIFFITHS, R.T. POLLARD, H. LEACH, S. HOLLEY, T. PAYLOR, T.W.N. HAINE, A. RIOS, S.G. ALDERSON, R.K. LOWRY, P. SMITH, M. PRESTON, T.J.P. GWILLIAM, J. SMITHERS, S. KEENE, J. HEMMINGS and T.R. ANDERSON (1992) CTD oxygen, tracer and nutrient data from RRS Charles Darwin Cruises 58/59 in the NE Atlantic as part of Vivaldi '91. Institute for Oceanographic Sciences Deacon Laboratory, Report No.296, $51 \mathrm{pp}$.

HAINE, T.W.N., A.J. WATSON and M.I. LIDDICOAT (1995) Chlorofluorocarbon113 in the northeast Atlantic, Journal of Geophysical Research, 100, 10745-10753. HARVEY, J. (1982) $\theta$-s relationships and water masses in the eastern North Atlantic, Deep-Sea Research, 29, 1021-1033.

HARVEY, J. and M. ARHAN (1988) The water masses of the central North Atlantic in 1983-84, Journal of Physical Oceanography, 18, 1855-1875.

HELLAND-HANSEN, B. and F. NANSEN (1926) The eastern North Atlantic, Geophysiske Publicajoner, 4, 1-76.

HOGG, N.G. (1992) On the transport of the Gulf Stream between Cape Hatteras and the Grand Banks, Deep- Sea Research, 39, 1231-1246.

HOGG, N.G. (1993) Towards parameterization of the eddy field near the Gulf Stream, Deep-Sea Research, 40, 2359-2376.

ISELIN, C.O'D. (1936) A study of the circulation of the western North Atlantic, Papers in Physical Oceanography and Meteorology, 4, No. 4, 101 pp.

ISELIN, C.O'D. (1939) The influence of vertical and horizontal turbulence on the characteristics of waters at mid-depths, Transactions of the American Geophysical Union, 3, 414-417. 
JENKINS, W.J. (1982) On the climate of a subtropical ocean gyre: Decade timescale variations in water mass renewal in the Sargasso Sea, Journal of Marine Research, 40, 265-290.

KING, B.A., S.G. ALDERSON, S. BACON, T.J.P. GWILLIAM, C. HIRST, R. PAYLOR, J.F. READ and J.C.SWALLOW (1991) CTDO station data from the north east Atlantic from RRS Discovery cruise 189. Institute of Oceanographic Sciences Deacon Laboratory, Report No 287, 182 pp.

LEACH, H. (1990) Interannual variability in the upper ocean in the North Atlantic, summer 1983 and 1986, Deep-Sea Research, 37, 1169-1175.

LEETMAA, A. and A.F. BUNKER (1978) Updated charts of the mean annual wind stress, convergences in the Ekman Layers, and Sverdrup transports in the North Atlantic, Journal of Marine Research, 36, 311-322.

MCCARTNEY, M.S. (1982) The subtropical recirculation of Mode Waters, Journal of Marine Research, 40, 427-464.

MCCARTNEY, M.S. and L.D. TALLEY (1982) The Subpolar Mode Water of the North Atlantic Ocean, Journal of Physical Oceanography, 12, 1169-1188.

MEINCKE, J. (1986) Convection in the oceanic waters west of Britain, Proceedings of the Royal Society of Edinburgh, 88B, 127-139.

NEW, A.L. and R. BLECK (1995) An isopycnic model study of the North Atlantic. Part II: interdecadal variability of the subtropical gyre, Journal of Physical Oceanography, 25, 2700-2714.

ONKEN, R. (1993) The Azores countercurrent, Journal of Physical Oceanography, 23, $1638-1646$.

PAILLET, J. and M. ARHAN (1996) Oceanic ventilation in the eastern North Atlantic, Journal of Physical Oceanography, in press.

PEREZ, F.F., A.F. RIOS, B.A. KING and R.T. POLLARD (1995) Decadal changes of the $\theta / \mathrm{S}$ relationship of the eastern North Atlantic Central Water, Deep-Sea Research, $42(11 / 12), 1849-1864$.

PINGREE, R.D. and B. LE CANN (1990) Structure, strength and seasonality of the slope currents in the Bay of Biscay region, Journal of the Marine Biological Association, 70, 857-885.

POLLARD, R.T. (1986) Frontal surveys with a towed profiling conductivity/temperature/depth measurement package (SeaSoar), Nature, 323, 433435. 
POLLARD, R.T., H. LEACH and G. GRIFFITHS (1991) RRS Charles Darwin Cruises 58 \& 5925 April- 16 May; 18 May-10 Jun 1991 Vivaldi '91. Institute of Oceanographic Sciences Deacon Laboratory, Report no. 228, 49 pp.

POLLARD, R.T. and S. PU (1985) Structure and circulation of the upper Atlantic Ocean northeast of the Azores, Progress in Oceanography, 14, 443-462.

READ, J.F., R.T. POLLARD and C. HIRST (1991) CTD data from the north east Atlantic, April 1989, collected on RRS Discovery Cruise 181. Institute of Oceanographic Sciences Deacon Laboratory, Report 285, 157 pp.

RIOS, A.F., F.F. PEREZ and F. FRAGA (1992) Water masses in the upper and middle North Atlantic ocean east of the Azores, Deep-Sea Research, 39, 645-658.

SCHMITZ, W.J.Jr and M.S. MCCARTNEY (1993) On the North Atlantic circulation, Reviews of Geophysics, 31, 29-49.

STRAMMA, L. (1984) Geostrophic transport in the warm water sphere of the eastern subtropical North Atlantic, Journal of Marine Research, 42, 537-558.

SY, A. (1988) Investigation of large-scale circulation patterns in the central North Atlantic: the North Atlantic Current, the Azores Current, and the Mediterranean Water plume in the area of the Mid-Atlantic Ridge, Deep-Sea Research, 35, 383413.

SY, m., U. SCHAUER and J. MEINCKE (1992) The North Atlantic Current and its associated hydrographic structure above and eastwards of the Mid-Atlantic Ridge, Deep-Sea Research, 39, 825-853.

TSUCHIYA, M., L.D. TALLEY and M.S. MCCARTNEY (1992) An eastern Atlantic section from Iceland southward across the equator, Deep-Sea Research, 39, 18851971. 
Fig. 1 The Vivaldi cruise track. Six "parallel" lines 300 km apart were occupied, labelled $\mathrm{W}, \mathrm{X}, \mathrm{Y}, \mathrm{Z}, \mathrm{A}$ and $\mathrm{B}$. Line $\mathrm{Z}$ ran due north-south along $20^{\circ} \mathrm{W}$. On each line, CTD casts to full depth were made at $39^{\circ} \mathrm{N}, 42^{\circ} \mathrm{N}, 45^{\circ} \mathrm{N}, 48^{\circ} \mathrm{N}, 51^{\circ} \mathrm{N}$ and $54^{\circ} \mathrm{N}$. Cast positions are thus identified in the text as (for example) Z48.Darwin Cruise 58 ran from the UK to the Azores, occupying stations and sections from $48^{\circ} \mathrm{N}$ southwards. Cruise 59 ran from the Azores northwards along Line W, then back to the UK surveying from $48^{\circ} \mathrm{N}$ northwards. Several stations and SeaSoar sections along $48^{\circ} \mathrm{N}$ were therefore occupied twice. To allow comparison with earlier work, TOPOGULF cruise tracks (HARVEY and ARHAN, 1988; SY, 1988) are shown lightly dotted. $1000 \mathrm{~m}$ (solid) and $3000 \mathrm{~m}$ (dotted) contours are also shown.

Fig. 2 Assuming a zero velocity reference level of $2000 \mathrm{~m}$, the transport between the surface and $2000 \mathrm{~m}$, calculated from the $300 \mathrm{~km}$ separated CTD casts, is shown as a stream function in Sverdrups $\left(1 \mathrm{~Sv}=10^{6} \mathrm{~m}^{3} \mathrm{~s}^{-1}\right)$, arbitrarily starting from zero at the northwest comer of the Vivaldi survey area. Also shown (dashed lines) are the positions of the northern and southern branches of the NAC determined from the SeaSoar data.

FIG. 3. Sections of (a) potential temperature $(\theta)$, (b) (overpage) salinity (s) and (c) (overpage) density $\left(\sigma_{0}\right)$ from $0 \mathrm{~m}$ to $500 \mathrm{~m}$, for the six meridional lines, $\mathrm{W}$ (top), $\mathrm{X}, \mathrm{Y}$, Z, A and B (bottom). To allow identification of stads, all contours are plotted at'even intervals for each variable. Northern and southern branches of the NAC are marked N and $\mathrm{S}$ on $(\mathrm{c})$.

Fig. 4 Temperature contours at $0.2^{\circ} \mathrm{C}$ intervals for 50 latitude extracts from lines $\mathrm{W}, \mathrm{Y}$, $\mathrm{Z}$ and $\mathrm{B}$ highlight some of the thermostads apparent in Fig. 3a. Bold lines show integer degrees. The thermostad $12.8^{\circ} \mathrm{C}-13.2^{\circ} \mathrm{C}$ is lightly shaded and $12.0^{\circ} \mathrm{C}-12.4^{\circ} \mathrm{C}$ is medium shaded. The dark shade is $10.6^{\circ} \mathrm{C}-10.8^{\circ} \mathrm{C}$ for line $\mathrm{Y}$ and $11.6^{\circ} \mathrm{C}-11.8^{\circ} \mathrm{C}$ for line $\mathrm{B}$.

Fig. $5 \theta / \mathrm{S}$ scatter plots for each of the six meridional lines W through $\mathrm{B}$, from SeaSoar data gridded at $4 \mathrm{~km}$ intervals along track and $4 \mathrm{~m}$ in the vertical from $0-500 \mathrm{~m}$. The reference line V91 (Fig. 6 and Table 1) was fitted by eye to line W. The X-axis scale is that for line W. Other lines are offset by salinity increments of 0.4 . 
Fig. 6 Central Water $\theta / \mathrm{S}$ relationships derived by several authors (HARVEY, 1982; ISELIN, 1936; RIOS, PEREZ and FRAGA, 1992) are compared with the V91 curve for water within the NAC and the maximum salinity curve for ENAW on lines A and B. The $30^{\circ} \mathrm{W}$ line derived from ISELIN (1936) is referred to as I31 in the text and Table 1. The SAIW diamond is taken from HARVEY and ARHAN (1988). LSW marks the salinity minimum of Labrador Sea Water obtained for Vivaldi CTD W51.

FIG. 7. Sections of salinity

Fig. 8 g/S scatter plot for all the CTD casts. Two solid lines mark the breaks between high salinity water with clear Mediterranean Water influence and low salinity water with SAIW influence. $\theta / \mathrm{S}$ values between the two lines, showing no obvious influence from either of these two sources, come from casts W42, W45 and X45 and some depths on Z48, Z51 and Z54.

Fig. 9. Zonal section of (a) potential temperature, (b) salinity, (c) density and (d) salinity anomaly along $54^{\circ} \mathrm{N}$ between lines $\mathrm{Y}$ and $\mathrm{Z}$ show the northward flowing NAC. The sudden changes at $23.5^{\circ} \mathrm{W}$ and $21.8^{\circ} \mathrm{W}$ correspond, respectively, to the northern and southern branches of the NAC.

Fig. 10 One example of the correlation between thickness (the pressure difference between two isopycnals) and mean salinity anomaly (the salinity anomaly as defined in Fig. 7, averaged between the chosen isopycnals) is shown for each of the lines $\mathrm{W}$ through B. For line W, the isopycnals 27.00 and 27.05 (discussed in Section 4.2) are chosen, but for all other lines the values 27.05 and 27.15 (Section 4.1) are used. The thickness scale (0-400 dbar) is therefore doubled for line W. A clear correlation is apparent between areas of enhanced thickness (pycnostads) and areas of positive salinity anomaly.

Table 1 Central Water salinities.

\begin{tabular}{llllllll}
\hline Temperature & Iselin $^{1}$ & Iselin $^{2}$ & Vivaldi & I31 & V91 & Vivaldi & Rios $^{3}$ \\
$\left({ }^{\circ} \mathrm{C}\right)$ & WNAW & $30^{\circ} \mathrm{W}$ & line W & - & $-\mathrm{I} 31$ & ENAW & ENAW \\
& & I31 & V91 & WNAW & & max & \\
& & & & & &
\end{tabular}




\begin{tabular}{llllllll}
\hline 16 & 36.16 & 36.15 & 36.23 & -0.01 & 0.08 & & 36.31 \\
15 & 36.00 & 36.00 & 36.08 & 0.00 & 0.08 & & 36.13 \\
14 & 35.81 & 35.84 & 35.93 & 0.03 & 0.09 & & 35.95 \\
13 & 35.67 & 35.70 & 35.78 & 0.03 & 0.08 & 35.87 & 35.78 \\
12 & 35.53 & 35.55 & 35.63 & 0.02 & 0.08 & 35.71 & 35.64 \\
11 & 35.39 & 35.40 & 35.48 & 0.01 & 0.08 & 35.55 & 35.52 \\
10 & 35.28 & 35.28 & 35.33 & 0.00 & 0.05 & 35.40 & 35.40 \\
9 & 35.19 & 35.14 & 35.19 & -0.05 & 0.05 & 35.25 & 35.31 \\
8 & 35.12 & 35.00 & 35.05 & -0.12 & 0.05 & & 35.22 \\
7 & 35.07 & & 34.93 & & & & 35.16 \\
6 & 35.03 & & 34.83 & & & & 35.09 \\
\hline
\end{tabular}

Notes:

1. Sargasso Sea values taken from ISELIN (1936), Fig. 22.

2. $30^{\circ} \mathrm{W}$ in 1931, taken from ISELIN (1936), Fig. 31.

3. Above $10^{\circ} \mathrm{C}$, from Rios, PEREZ and FRAGA (1992), below $10^{\circ} \mathrm{C}$, from HARVEY (1982). 